\title{
PELATIHAN BUDIDAYA JAMUR TIRAM SEBAGAI PROGRAM PEMBERDAYAAN SANTRI DI PESANTREN ANNUR FATMAH, DESA BELIK, KABUPATEN MOJOKERTO
}

\section{TRAINING ON OYSTER MUSHROOM CULTIVATION AS THE EMPOWERMENT PROGRAM FOR STUDENTS OF ANNUR FATMAH ISLAMIC BOARDING SCHOOL IN BELIK MOJOKERTO}

\author{
Achmad Toto Purnomo \\ Departemen Kimia Farmasi, Fakultas Farmasi, Universitas Airlangga, Kampus B, Jl. Dharmawangsa Dalam, Surabaya, \\ 60286, Indonesia. Tel/fax: +62-31-5030-710/+62-31-5020-514, E-mail: achmad.toto.p@gmail.com \\ Djoko Agus Purwanto \\ Departemen Kimia Farmasi, Fakultas Farmasi, Universitas Airlangga, Kampus B, Jl. Dharmawangsa Dalam, Surabaya, \\ 60286, Indonesia. Tel/fax: +62-31-5030-710/+62-31-5020-514, E-mail: djokoagus@ff.unair.ac.id
}

\begin{abstract}
Abstrak
Program pemberdayaan masyarakat melalui usaha budidaya jamur tiram ini dirancang sebagai upaya untuk memberikan nuansa kesetaraan, kemitraan, dan kebersamaan untuk perbaikan ekonomi masyarakat. Pondok pesantren Annur Fatmah, dengan potensi sumber daya manusia dan alamnya yang melimpah, dapat menjadi bagian dalam proses perubahan sosial. Pemberdayaan santri di pesantren ini ditujukan supaya santri dapat melakukan sesuatu yang bermanfaat bagi masyarakat, antara lain melalui program pelatihan dan pendampingan dalam usaha budidaya jamur tiram (Pleorotus spp). Dengan didampingi oleh Tim Lembaga Penelitian dan Pengabdian kepada Masyarakat (LPPM) Universitas Airlangga, kegiatan ini dilaksanakan kepada para santri pondok pesantren Annur Fatmah di desa Belik, Trawas, Mojokerto melalui pemberian teori dan praktek lapangan tentang budidaya jamur. Kegiatan pengabdian kepada masyarakat ini telah berhasil membentuk industri kecil yang mampu memberikan pendapatan bagi santri di pondok pesantren Annur Fatmah di Desa Belik, Mojokerto.
\end{abstract}

Kata kunci: budidaya, jamur tiram, pemberdayaan, santri, Trawas.

\begin{abstract}
A community empowerment program through training program on cultivation of Pleorotus spp mushrooms is designed as an effort to give the equality, partnership, and togetherness for improving the economic condition of social community. Islamic boarding school Annur Fatmah has potential human and natural resources, thus empowering the students of this school could provide many benefits, especially for good social changes. The program was carried out in the Annur Fatmah Islamic Boarding School in Belik village, Trawas, Mojokerto accompanied with the teams of Institute for Research and Community Service (LPPM) of Universitas Airlangga. The activities involved theory and practice for mushroom cultivation. The participants successfully cultivated mushroom for 2,500 bag-log scale production. This community empowerment activity could facilitate economic improvement by providing home income for students of Annur Fatmah Islamic Boarding School in Belik village, Mojokerto.
\end{abstract}

Keywords: cultivation, empowerment, mushroom, santri, Trawas.

\section{PENDAHULUAN}

Pondok pesantren Annur Fatmah, yang berdiri di desa Belik, Trawas, Mojokerto, menyimpan potensi yang luar biasa, akan tetapi selama ini masih belum dimanfaatkan dengan baik. Potensi tersebut antara lain: (1) sumberdaya manusia yaitu para santri yang jumlahnya dapat mencapai ratusan orang; (2) kepemilikan lahan yang luas, terutama yang terletak di pusat pendidikan; (3) potensi pasar yang tinggi, mengingat adanya hubungan sosial dan kekerabatan antara lembaga keagamaan dengan masyarakat sekitarnya; (4) potensi teknologi, dimana merupakan lembaga strategis untuk mengembangkan teknologi, dan (5) kepemimpinan dari para kyai sebagai pemimpin pondok pesanten yang ditaati dan kharismatik. 
Pondok pesantren Annur Fatmah juga dipahami sebagai bagian yang terlibat dalam proses perubahan sosial (social change) di tengah perubahan yang terjadi. Sedangkan tujuan yang ingin dicapai dalam mencetak kader-kader pemberdayaan masyarakat tersebut, seperti yang ditetapkan oleh pondok pesantren Annur Fatmah, adalah: (1) menumbuh-kembangkan jiwa wirausaha di kalangan santri dan masyarakat; (2) menumbuh-kembangkan sentra dan unit usaha yang berdaya saing tinggi; (3) membentuk Lembaga Ekonomi Mikro berbasis nilai Islam; dan (4) mengembangkan jaringan ekonomi dan pendanaan di pesantren baik horisontal maupun vertikal.

Pemberdayaan santri di pesantren Annur Fatmah merupakan suatu proses yang ditujukan untuk memberikan kemampuan kepada para santri sehingga mampu melakukan sesuatu yang bermanfaat (Nasdian 2003). Salah satu upaya untuk program pemberdayaan ini adalah melalui program pelatihan dan pendampingan.

Dalam pelaksanaan program pelatihan dan pendampingan, diperlukan ketersediaan sumberdaya manusia (SDM) yang berkualitas sebagai fasilitator, komunikator, dan dinamisator selama program berlangsung dan berfungsi sebagai konsultan sewaktu diperlukan oleh kelompok masyarakat. Perubahan perilaku para santri untuk mandiri dan kreatif dalam mengembangkan usaha produktif merupakan fokus program pelatihan dan pendampingan ini (Sumardjo dan Firmansyah 2015). Tenaga pendamping berasal dari Tim Lembaga Penelitian dan Pengabdian kepada Masyarakat (LPPM) Universitas Airlangga.

Sebagai sebuah program, pelatihan dan pendampingan tidak hanya sekedar bertatap muka, saling memberi dan menerima. Namun, lebih dari itu, program ini merupakan sebuah momentum membangun hubungan emosional. Kegiatan ini memungkinkan terjadinya proses berbagi keterampilan dan pengalaman baik professional, maupun personal yang mendorong proses tumbuh dan berkembang sepanjang proses yang terjadi. Dalam wujudnya yang paling efektif, pendampingan adalah kemitraan pembelajaran yang melibatkan kerjasama dan peluang untuk menghadapi tantangan dan melakukan refleksi berkelanjutan antara Universitas Airlangga dengan para santri pondok pesantren Annur Fatmah.

Program pemberdayaan masyarakat melalui usaha budidaya jamur tiram (Pleorotus spp), ini dirancang sebagai upaya untuk memberikan nuansa kesetaraan, kemitraan dan kebersamaan sebagai landasan bagi proses pendampingan yang harmonis. Selain itu pasar domestik maupun global masih terbuka luas sehingga disamping meningkatkan perekonomian rakyat sekaligus juga menghasilkan devisa, dan diharapkan mampu menampung kebutuhan masyarakat, membangun kemampuan dalam meningkatkan pendapatan, melaksanakan usaha yang berskala bisnis serta mengembangkan perencanaan dan pelaksanaan kegiatan yang partisipatif.

\section{METODE PELAKSANAAN}

Kegiatan yang dilakukan terdiri atas beberapa tahap, yaitu: pembekalan, pelatihan dan pendampingan. Kegiatan pembekalan meliputi beberapa aspek, yaitu: pembekalan teori dan teknis budidaya jamur tiram putih (Pleurotus florida) antara lain pengenalan tentang jamur tiram putih, teknik produksi dan persiapan budidayanya (peralatan apa saja yang digunakan dalam budidaya jamur), teknik pembuatan bibit, teknik pembuatan media tanam/bag-log, teknik membuat rumah jamur/kubung, dan produk olahan jamur.

Selain itu, juga dilakukan pembekalan mengenai aspek pemodalan, analisis usaha sederhana, pemasaran, akses informasi dunia usaha, dan bagaimana membentuk jalinan kerjasama. Kegiatan ini juga meliputi kegiatan praktek di lapangan/tempat usaha jamur yang sudah ada di daerah Malang dengan pembuatan rumah jamur dan budidayanya selama 2 hari.

Tahap berikutnya, yaitu pelatihan, dilakukan dengan beberapa metode, yaitu: tutorial, diskusi, dan praktek lapangan dalam kelompok yang terdiri dari 5 orang. Pelatihan dilakukan kepada sebanyak 4 kelompok. Tiap peserta dibekali dengan bibit jamur dan peralatan yang digunakan untuk budidaya tersebut.

Adapun tahap pendampingan pasca praktek lapangan dilakukan dengan melakukan kunjungan setiap 2 minggu untuk memantau kegiatan para santri karena pendamping sudah mempersiapkan atau melatih para santri tersebut untuk mandiri. Pendampingan secara langsung dilakukan oleh dua orang pendamping dari LPPM Unair yang ikut terlibat secara langsung dalam proses budidaya jamur dengan ikut mempelajari serta mengontrol pertumbuhan jamur. Selanjutnya dilakukan wawancara, dialog, dan diskusi untuk mengumpulkan data dan menganalisis permasalahan yang terjadi selama pertumbuhan jamur. Selain itu, juga dilakukan pendampingan saat penentuan pemanenan dan penangananan pasca panen

\section{HASIL DAN PEMBAHASAN}

Pengabdian kepada Masyarakat telah terlaksana atas kerjasama antara LPPM Universitas Airlangga dengan pimpinan Pondok Pesantren Annur Fatmah di desa Belik, Kecamatan Trawas, Kabupaten Mojokerto. Dengan sumber daya dan kondisi alam yang cocok untuk budidaya jamur tiram, program pengembangan budidaya tanam jamur tiram dapat menjadi salah satu kegiatan pemberdayaan yang memberikan satu bentuk ketrampilan bagi pimpinan dan siswa pondok sehingga mampu menciptakan penghasilan baru bagi Pondok Pesantren tersebut. Tidak hanya berupa pelatihan, tapi juga dilakukan kegiatan pendampingan untuk memastikan bahwa para peserta telah mampu melaksanakan hasil pelatihan dengan baik. 


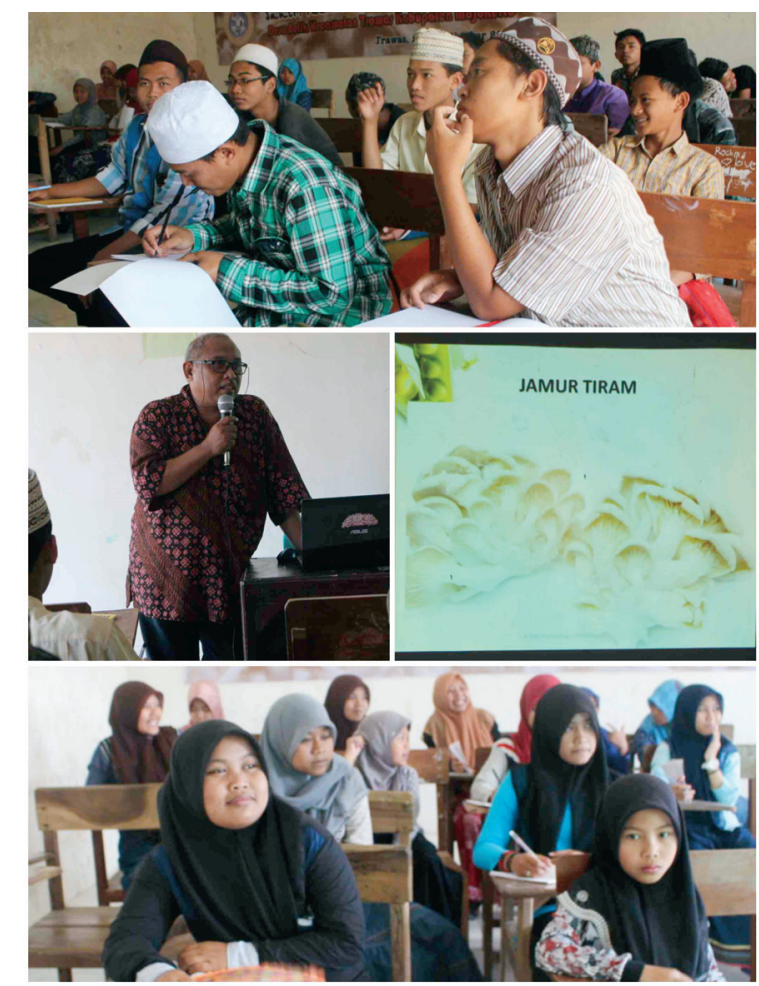

Gambar 1. Suasana pelatihan secara teori yang diikuti peserta santri putri dan putra

Pada saat awal kegiatan, dilakukan kegiatan pelatihan yang berisi materi guna pembekalan teori dan teknis budidaya jamur tiram putih (Gambar 1). Setelah itu, dilakukan kegiatan praktek lapangan budidaya jamur untuk skala 2.500 baglog. Adapun materi teori dan praktek yang diberikan kepada peserta meliputi:

\section{Pengenalan tentang jamur}

Menyajikan berbagai jenis jamur untuk dibudidayakan. Dipilih jamur tiram putih yang sudah banyak diminati oleh masyarakat dan menawarkan keistimewaan antara lain kandungan protein, vitamin, mineral, dan serat yang tinggi sehingga sesuai untuk diet makanan.

\section{Cara membuat media PDA (potatoes dextrose agar)}

Dilakukan kajian tentang bagaimana metode dan cara mempersiapkan pembuatan media untuk pembibitan jamur tiram putih. Metode ini hanya diberikan secara teoritis, mulai pemilihan jamur yang baik untuk bibitm teknik aseptis, teknik inokulasi sampai dengan penumbuhan pada media F1 dan F2 yang dikemas dalam botol.

\section{Memilih kultur jaringan}

Jamur yang masih muda, segar dan sehat digunakan untuk menyiapkan kultur jaringan. Prosedur ini harus telaten dan membutuhkan pemahaman yang luas serta lingkungan yang sangat bersih.

\section{Membuat bibit turunan}

Yakni menginokulasikan bibit pada biji sorgum. Pada bagian ini, hanya teori dasar yang akan diberikan di kelas. Santri diharapkan memahami bagaimana memilih dan membeli kualitas bibit yang baik dari berbagai pemasok. Mereka juga harus mengetahui semua langkah yang terlibat dalam budidaya jamur untuk memungkinkan ekspansi masa depan pertanian jamur mereka.

\section{Memproduksi media bag-log}

Praktek produksi bag-log dibutuhkan oleh peserta pelatihan untuk memastikan bahwa mereka dapat memproduksi baglog bibit sendiri atau dapat memverifikasi kualitas bag-log. Pada kegiatan ini, peserta melakukan praktek lapangan di petani jamur Slawi (Gambar 2).

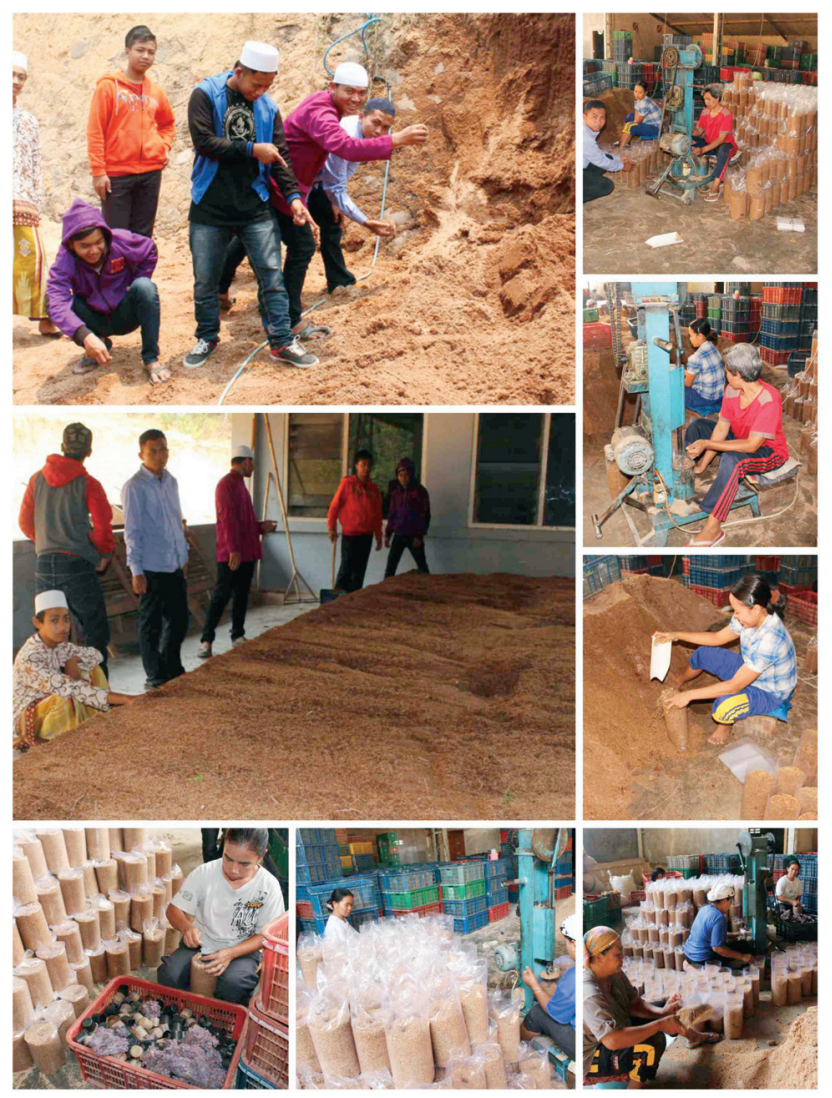

Gambar 2. Praktek lapangan di produksi bag-log petani jamur Slawi

\section{Sterilisasi bag-log}

Sterilasi dengan uap panas dan tekanan benar-benar diperlukan untuk sterilisasi bag-log. Jika bag-log tidak disterilkan dengan benar, yang dimungkinkan karena waktu yang tidak cukup di ruang pasteurisasi atau karena suhunya yang tidak cukup, maka akan mengakibatkan bag-log akan terkontaminasi oleh pertumbuhan jamur yang buruk atau terjadi pembusukan pada bag-log. 


\section{Inokulasi bag-log dengan media biji sorgum}

Inokulasi harus dilakukan dengan sangat hati-hati. Ini merupakan langkah yang sangat halus yang akan memastikan hasil yang lebih tinggi dengan penyakit kantong substrat gratis. Pekerjaan harus dilakukan di dekat nyala api dari lampu alkohol selama inokulasi.

\section{Inkubasi}

Selama inkubasi, kelembaban, cahaya, suhu dan ventilasi harus dipantau terus-menerus. Waktu inkubasi akan berbeda sesuai dengan jenis jamur dan kondisi iklim.

\section{Pembukaan bag-log}

Setelah inkubasi, tutup jamur harus dibuka sesuai dengan jenis jamur.

\section{Memelihara dan pemantauan}

Pemeliharaan rumah jamur sangat penting untuk hasil yang lebih tinggi. Ketika ruangan tetap bersih, ada serangga kurang dan hama, maka akan menghindari dari penyakit . Bag-log harus diperiksa secara individual dan tetap bersih sebagaimana yang telah dipraktekkan oleh peserta kegiatan (Gambar 3).

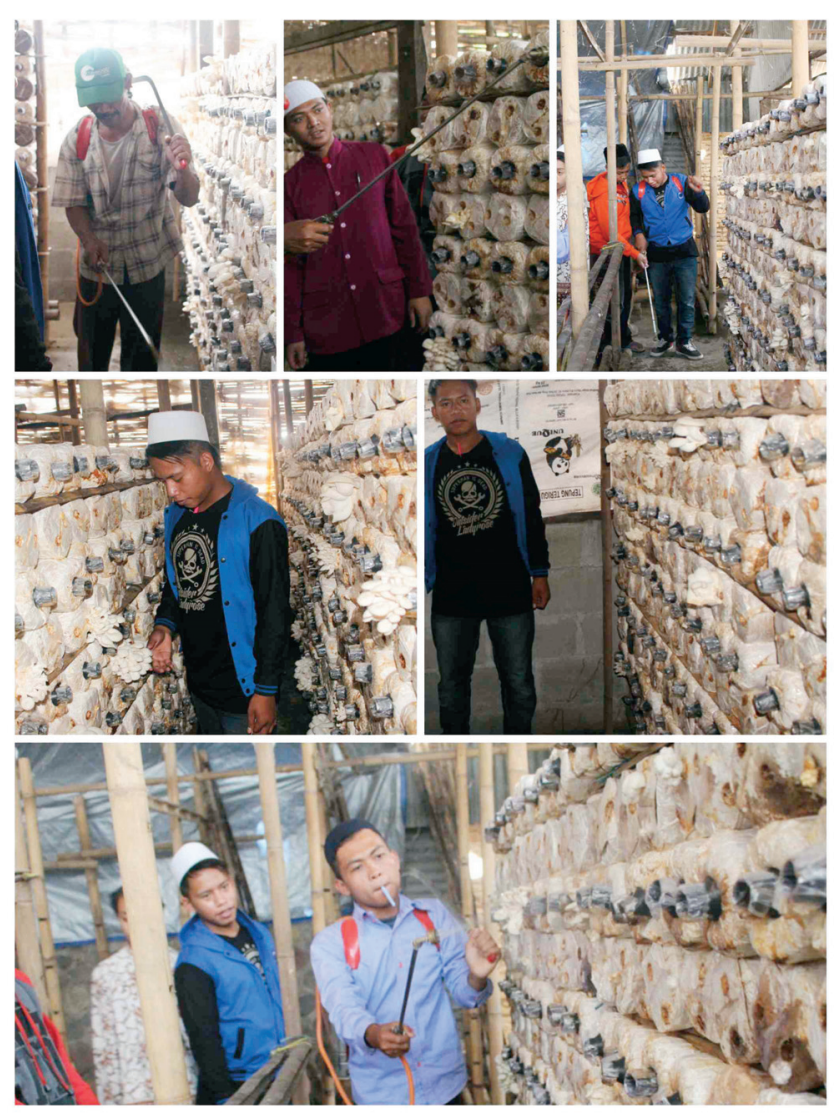

Gambar 3. Pemeliharaan miselium jamur dengan penyemprotan air.

\section{Pemanenan}

Pemanenan dilakukan setidaknya dua kali sehari untuk memastikan bahwa jamur yang dipilih muda dan sehat, sebagaimana yang dipraktekkan oleh peserta kegiatan (Gambar 4). Ketika dipanen pada waktu yang tepat, tidak terlalu besar, jamur dapat terus tumbuh untuk waktu yang lama dan rasanya lebih manis dan lebih lezat. Tergantung pada jenis jamur, satu bag-log dapat menghasilkan total 250 sampai 500 gram jamur.
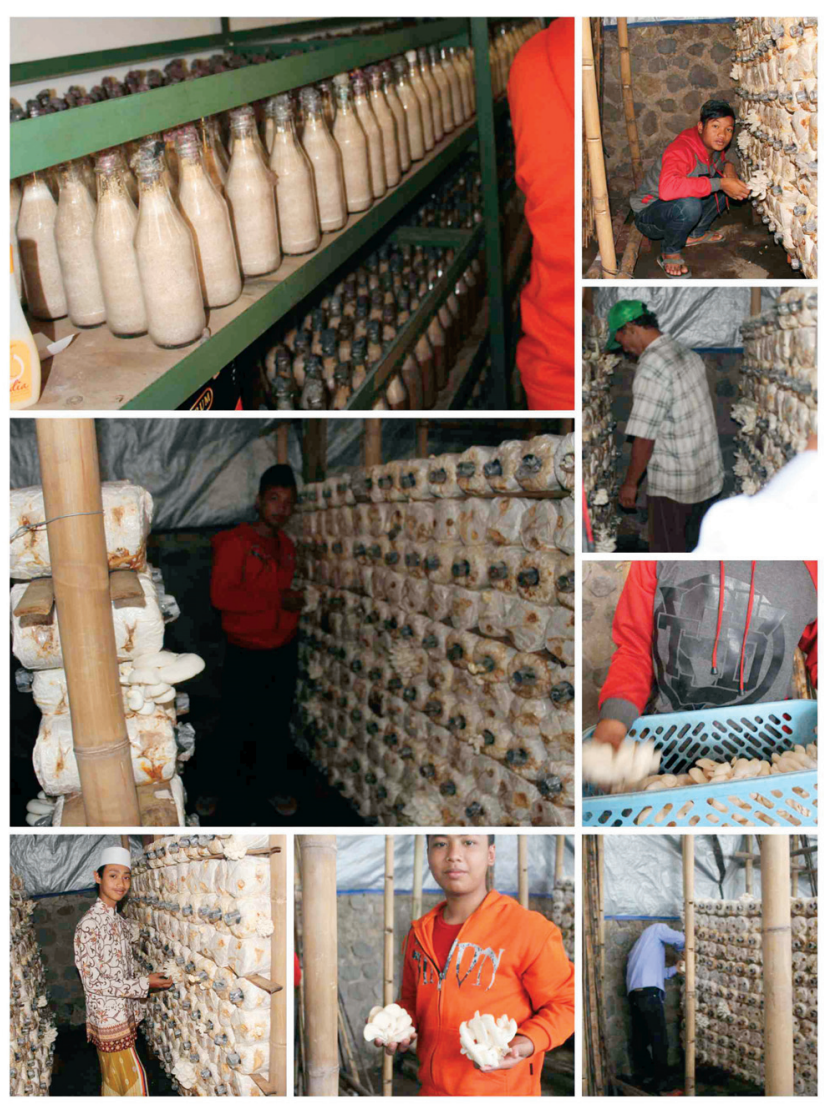

Gambar 4. Panen jamur tiram

\section{Pengemasan}

Jamur harus dijual dalam keadaan segar atau dari kubung langsung dengan atau tanpa kemasan. Kebanyakan yang membeli dapat menggunakan plastik atau kertas kantong.

\section{Pemasaran}

Pemasaran tetap kunci sebuah usaha yang sukses sehingga diperlukan kejelian dalam proses pemasaran produk, misalnya dengan adanya diskon serta kualitas jamur yang baik.

\section{Pengolahan}

Sudah ada banyak metode dan resep yang dapat menawarkan nilai tambah produk jamur. Namun demikian, di daerah pedesaan, yang mana memiliki keterbatasan 
keuangan, pengelolaan harus dibuat sedemikian agar tidak terjadi kerugian.

\section{Pengelolaan limbah dan daur ulang}

Limbah harus ditangani dengan baik dalam setiap langkah dari proses budidaya jamur. Daur ulang dan pemanfaatan limbah tidak hanya cara yang baik untuk melestarikan lingkungan, tetapi juga menghemat uang bahkan menghasikan uang, yaitu dengan cara digunakan untuk pemeliharaan budidaya cacing tanah.

\section{Pemecahan masalah}

Hal ini diperlukan untuk mengetahui masalah yang paling umum ditemukan dalam produksi jamur, gejala dan pengobatannya. Hal ini akan membantu memecahkan masalah dasar dan membantu mengidentifikasi masalah sebelum terjadi.

\section{Memulai bisnis}

Sebagai seorang pengusaha dalam produksi jamur, maka perlu memiliki pengetahuan dasar dalam manajemen dan pembukuan. Hal ini akan memungkinkan pelacakan keuntungan dan kerugian.

\section{Menjaga catatan}

Menjaga catatan sangat penting karena memungkinkan pemantauan semua biaya yang dikeluarkan dalam produksi jamur. Hal ini juga memungkinkan untuk memverifikasi berapa banyak keuntungan yang dihasilkan dalam bisnis dan mengidentifikasi bagaimana biaya-biaya tertentu dapat dikurangi untuk menghasilkan lebih banyak keuntungan.

Guna keberlanjutan pengembangannya, semuanya diserahkan kepada pimpinan pondok dan anak bimbing yang ada. Tim pelaksana berusaha untuk memantau dan siap mendampingi serta memotivasi anak bimbing pondok sehingga mereka tidak antusias hanya pada saat pelatihan berlangsung, tetapi juga setelah selesai. Dengan demikian, program ini benar-benar diminati sehingga bisa berkembang dengan baik. Hal ini diupayakan sebagai upaya agar mereka bisa membuka usaha jamur tiram yang mampu menciptakan pendapatan baru bagi keberlanjutan kehidupan pondok pesantren.

Kegiatan pengabdian kepada masyarakat ini mampu membentuk industri kecil yang mampu memberikan income bagi Pondok Pesantren Annur Fatmah. Adanya keseriusan dan konsistensi pimpinan dan anak didik pondok memungkinkan tujuan akhir kegiatan akan tercapai, yaitu mengembangkan jarum tiram. Pondok Pesantren dan penduduk di sekitarnya bisa menciptakan pendapatan baru, dalam rangka peningkatan kehidupan yang lebih baik. Untuk mewujudkan harapan pimpinan dan pondok Pesantren dalam rangka menciptakan income baru, mereka harus konsisten serta mau mengembangkan ketrampilan yang sudah dimiliki. Aparat desa dengan dukungan dari pemerintah daerah setempat diharapkan dapat bertindak sebagai motivator dan menyediakan dana guna meningkatkan serta mengembangkan produksi jamur tiram.

\section{SIMPULAN}

Kegiatan pelatihan tentang budidaya jamur telah diberikan kepada para santri pondok pesantren Annur Fatmah di Desa Belik, Kabupaten Mojokerto. Melalui kegiatan pembelajaran di kelas, magang, serta praktek lapangan, para peserta telah berhasil membudidayakan jamur tiram dalam skala yang layak untuk dipasarkan. Kegiatan pelatihan ini telah berhasil memberikan manfaat bagi pengembangan kemampuan kewirausahaan para santri. Dari hasil budidaya jamur yang telah dilakukan, usaha ini berpotensi untuk dikembangkan lebih lanjut sebagai modal peningkatan ekonomi kemasyarakatan, khususnya bagi para santri di Pondok Pesantren Annur Fatmah, Mojokerto.

\section{UCAPAN TERIMA KASIH}

Kegiatan ini didanai oleh dana hibah IPTEKS bagi Masyarakat (IbM) dari Kementrian Riset, Teknologi, dan Perguruan Tinggi, Indonesia.

\section{DAFTAR PUSTAKA}

Nasdian, F. T. 2003. Pengembangan Masyarakat (Community Development). Bogor: Institut Pertanian Bogor.

Sumardjo dan Firmansyah, A. 2015. "Inovasi Pemberdayaan Masyarakat Berbasis Sumber Daya Pangan di Sekitar Wilayah Operasional PT. Pertamina Asset 3 Subang Field". Agrokreatif 1:8-19. 